\title{
Duration of the final phase of mining area deformation process in the conditions of Upper Silesia (Poland)
}

\author{
Piotr Strzałkowski ${ }^{1}$ (1)
}

Received: 3 September 2020 / Accepted: 3 May 2021 / Published online: 17 May 2021

(c) The Author(s) 2021

\begin{abstract}
The ability to estimate the duration of mining impact on the surface is important for both active and decommissioned mines. It allows to plan rational land development and to assess the time of exploitation impact on buildings. The data concerns cases of exploitation with roof caving in 20 hard coal mines in Upper Silesia and cases of exploitation with hydraulic stowing in 4 mines. Based on the analysis of geological and mining documentation, the duration of the final stage of the subsidence process was established - from the end of mining operations to the final stage of the subsidence. It was assumed that the subsidence reached its final state when the increments between two consecutive measurements did not exceed $10 \mathrm{~mm}$. Further analyses were carried out using the regression method using the Statistica program, looking for the relationship between the duration of the final phase of the subsidence process and the quantities characterizing the operating conditions. The obtained results indicate a significant impact of the depth of exploitation and the value of the parameter characterizing the rock mass strength properties on the duration of the final phase of the deformation process. As a result of statistical analyses, appropriate empirical formulas were proposed. In the case of performing exploitation with caving and when the variation in the value of $\operatorname{tg} \beta$ parameter characterizing the rock mass is small, which currently occurs in the considered basin, one can use the proposed formula, linking the duration of the process with the depth of mining exploitation.
\end{abstract}

Keywords Mining extraction $\cdot$ Mining subsidence $\cdot$ Final phase of deformations

\section{Introduction}

Conducting underground mining has a very wide impact on the environment, which unfortunately is usually an unfavorable influence (Bell et al. 2000; Bell and Donnelly 2006). Carrying out mining exploitation, regardless of geological and technical conditions, causes formation of continuous deformations on the surface. They appear in the form of subsidence troughs and derivatives of subsidence - the socalled deformation indices. There are several methods for calculating them (Whittaker and Reddish 1989; Kratzsch 1983; Peng 2008; Chudek 2002; Knothe 1953; Strzałkowski 2015; Orwat 2020). Mining area deformations pose a particular threat to building structures, often causing damage to them. Operating under favorable conditions also generates

Piotr Strzałkowski

piotr.strzalkowski@polsl.pl

1 Faculty of Mining, Safety Engineering and Industrial Automation, Silesian University of Technology, Akademicka 2, 44-100, Gliwice, Poland tremors to the rock mass, also posing a threat to building structures. The occurrence of tremors depends on a number of factors, both of natural origin (geological) and those related to the methods of conducting mining works. Rock mass tremors are associated with the presence of rocks capable of accumulating energy and releasing it rapidly. In the conditions of the Upper Silesian Coal Basin, these are mainly sandstones and some coal seams. Natural factors influencing values of the peak ground velocity (PGV) and peak ground acceleration (PGA) are geological faults (Ju et al. 2019a, b). Similarly, in the publication by Ju et al. (2019a, b), changes in the propagation of seismic waves were found as a result of faults. Exploitation in the area of faults may also cause the phenomenon of rock burst. In the work by Wu et al. (2020), the results of research in this area are presented, indicating the fault activation mechanisms. Methods of preventing rock bursts were also indicated. The activation of faults, which increases the continuous deformation and causes discontinuous deformation, carries a great risk. The activation of faults poses a great risk; it may 
increase the values of continuous deformations and cause discontinuous deformations (Ścigała and Szafulera 2019).

In the case of mines operating for many years and closed mines operating at shallow depths, discontinuous surface deformations (mainly sinkholes) are a significant problem. Caving of shallow galleries caused by subsequent exploitation, the phenomenon of suffusion, or rock mass tremors causes sinkholes' creation on the surface (Li and Liu 2017; Genis et al. 2018; Strzałkowski 2019, 2021).

Mining exploitation and its cessation cause water level changes in the rock mass and formation of flooded areas (Didier 2009).

From a practical point of view, a very important problem is knowing the duration of the deformation process (Strzałkowski and Ścigała 2020). This issue is of great importance, both in active and liquidated mines (Blachowski et al. 2009). Knowledge of the duration of the deformation process is especially crucial for engineers dealing with issues of construction in mining areas. It allows them to properly design and ensure building security and rationally design investments in mining areas (Karfakis 1993). Knowing the time of exploitation impact on buildings is also important when assessing the relationship of damage to buildings with mining. This resulted in interest in the problems mentioned above. Following the literature devoted to the issue of determining the duration of the deformation process, it can be noticed that the first papers were published in the 1950s.

In the publications (Kratzsch 1983; Orchard 1956-57; Orchard and Allen 1974), it was found that the subsidence by a few percent of the final value continues for some time (according to some researchers, e.g., Flaschentrager (1957), up to several years after carrying out the exploitation).

The results of the research on the duration of the deformation process in the form of diagrams are presented in the paper (Szpetkowski 1978). The author has made diagrams showing the course of ground subsidence over time depending on the depth of exploitation.

Further research results from the British basins were presented by (Psamehmetoglu 1972) stating that the process of subsidence lasts up to 4 months after the movable edge of the exploitation moves away from the point to a distance exceeding its range of influence.

The results of surveys conducted on the exploitations in Australia led (Kapp 1973) to the conclusion that the process of subsidence takes about 200 days after the end of exploitation.

Summing up the results of research from the German basins at the time, Kratzsch (1983) stated that the duration of the deformation process varies from 6 months to 5 years.

The results of research conducted in Great Britain are summarized in the paper (Yao and Reddish 1994), presenting the empirical relationship that allows calculating the duration of the deformation process, taking into account the depth of conducted exploitation and the geological conditions of its conduct. According to the authors, the test results are important for civil engineers.

The authors of the work (Wang and Deng 2012) presented the unique approach to the issue, using neural networks. Good compliance with the values observed was obtained.

Of course, the abovementioned observations and research results of the cited authors relate to the specific conditions in which the exploitation were carried out. Therefore, the experience gained in one coal basin cannot be directly applied in another one. The results of own research presented in the further part of the work prove a significant influence of the depth of exploitation, rock mass structure, the method of roof control, and the speed of the exploitation front progress. More information on the above subject is provided later in the paper.

The authors of the work (Chudek et al. 2000) proposed an empirical formula for exploitation carried out with caving:

$T_{k}=0.015 \frac{H}{(\operatorname{tg} \beta)^{0.5}}+2.394$

where.

$\mathrm{T}_{\mathrm{k}}$ - duration of deformation after the end of exploitation or after it has moved away beyond the range of impact, months.

$\mathrm{H}-$ depth of exploitation, $\mathrm{m}$

$\operatorname{tg} \beta-$ tangent of the angle of the range of main influences.

The formula applies if $230<\mathrm{H}<1030$ and $1.85<\operatorname{tg} \beta$ $<3.3$

For exploitation with hydraulic stowing the same authors (Chudek et al. 2000) suggested the following formula:

$T_{k}=0.081 \frac{H}{(\operatorname{tg} \beta)^{3}}+2.034$

The formula applies if $280 \mathrm{~m}<\mathrm{H}<555 \mathrm{~m}$ and $1.5<\operatorname{tg} \beta$ $<3.3$

In the publication (Strzałkowski and Ścigała 2010), the following formula was suggested for caving exploitation:

$T_{k}=0.042 \frac{H^{0.0948}}{(\operatorname{tg} \beta)^{0.609}}$

The formula applies if $270 \mathrm{~m}<\mathrm{H}<840 \mathrm{~m}$ and $1.6<\operatorname{tg} \beta$ $<3.3$

Further analyses led the authors to propose a simplified form of the formula (3):

$T_{k}=0.028 \frac{H}{(\operatorname{tg} \beta)^{0.5}}$

Of course, formula (4) is also correct for the depth range up to $840 \mathrm{~m}$. 
The compliance of the formula with measurement results was the subject of research in the paper (Strzałkowski and Ścigała 2020). In formulas (1)-(2), the parameter of S. Knothe's theory appears - $\operatorname{tg} \beta$ (Knothe 1953). It is used interchangeably with the parameter $r$ - radius of the range of main influences and remains in relation to it, which can be observed in Fig. 1. Therefore $\operatorname{tg} \beta=H / r$. The value of the $\operatorname{tg} \beta$ parameter depends on the mechanical properties of the rock mass, and in the conditions of Upper Silesia, it ranges from 1.6 to 2.5, and in the case of a rock mass with very low strength even about 3 .

The course of subsidence over time can be divided into several phases (Kratzsch 1983). In one of the recent works related to the subject of the course of surface subsidence over time, Cui et al. (2020) present the division of the course of surface subsidence into the following phases: initial, active, weakening, and residual. During the active phase, approx. $85 \%$ of the final value of the subsidence is revealed (Vervoort and Declercq 2017).

In order to calculate the value of annual increases in residual subsidence, a formula was developed to calculate the value of the coefficient of roof control for this phase subsidence process. Then, depending on the thickness of the seam, the value of subsidence in annual periods was calculated.

The duration of the subsidence process depends on a number of factors (Whittaker and Reddish 1989):

- distance of the point from the exploited field,

- degree of rock mass cracking,

- geological structure of the rock mass,

- speed of advance of the edge of extraction,

- thickness of the overburden,

- roof control system,

- stowing kind,

- occurrence of natural voids in the rock mass.

As can be seen from the presented literature review, the duration of the deformation process is influenced by many factors. It is difficult to take into account such a wide variety of factors into analysis. On the other hand, the knowledge of the above time interval is very important for practical reasons. This made it necessary to conduct research aimed at identifying the factors that have the greatest impact on the above-mentioned period of time. As part of this study, the relation between the duration of the final phase of surface displacements and the factors characterizing the geological and mining conditions of the exploitation was investigated. The data for analyzes were the results of geodetic measurements carried out with the use of technical leveling. Based on the analysis of geological and mining documentation, the duration of the final stage of the subsidence process was established - from the end of mining operations to the final stage of the subsidence. A more detailed definition of this appellation is provided later in the work. It was assumed that the subsidence reached its final state when the increments between two consecutive measurements did not exceed $10 \mathrm{~mm}$. Further analyses were carried out with the use of the linear regression method using the Statistica program, which allowed for the provision of appropriate empirical formulas, constituting the utilitarian result of the work. These formulas link the duration of the final phase of the subsidence process with the values characterizing the geological and mining conditions of the exploitation.

\section{Materials and methods}

\section{The adopted method of analysis}

The duration of the final phase of the deformation process was defined identically as in the publications (Chudek et al. 2000; Strzałkowski and Ścigała 2010). Two cases of the position of observation points can be distinguished here, as shown in Fig. 2. In the first one, the exploitation front moves under point P1 (Fig. 2 on the left side). After some time, it moves away from the point P1 by a distance of $r$
Fig. 1 Trough subsidence profile, radius of range of main influences $-r$ and angle of range of main influences $-\beta$

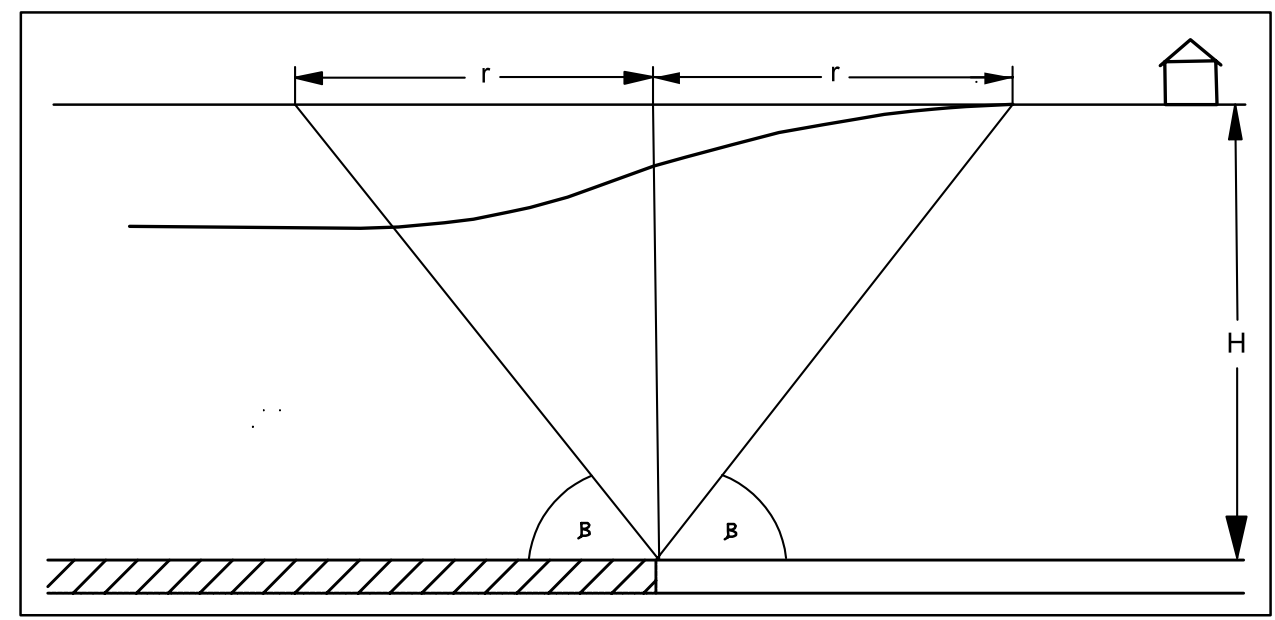


Fig. 2 Diagram illustrating the duration of the final phase of the deformation process depending on the location of the measurement points in relation to the exploitation field

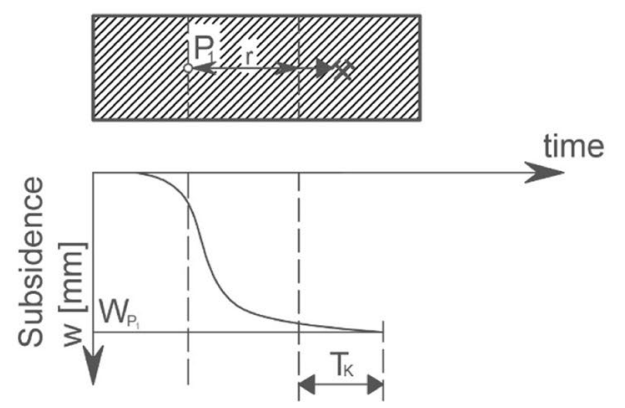

— radius of the range of main influence (see Fig. 1). From this point on, the exploitation front is at a distance that does not affect point P1. However, further subsidence occurs, but the values are low in comparison to those previously observed. The time that elapses since the displacement of the mining front at the distance $r$ from point $\mathrm{P} 1$ until the end of subsidence was defined as the duration of the final phase of the subsidence process. The simpler case is when the exploitation front stops at a distance of less than $r$ from the observation point - Fig. 2 on the right. Then, the duration of the final phase of the subsidence process was defined as the time interval from stopping of the exploitation front until the end of the subsidence process. The criterion allowing to establish when the subsidence process is completed is presented below.

It was assumed that the subsidence process was completed when the height of the point in two consecutive measurements did not differ by more than $10 \mathrm{~mm}$. This value results from the accuracy of the measurement performed by technical leveling. It can also be concluded that such a small monthly increase of subsidence does not affect the condition of most building structures. The diagram of both cases is shown in Fig. 2. The case where the measuring point was located near the motionless exploitation edge - point P2 was considered more reliable. Therefore, efforts were made to include for the analyses mainly the subsidence recorded in these points. Of course, the accuracy of determining the duration of the final phase of the deformation process depended to a large extent on the frequency of measurements. In the predominant number of analyzed cases, measurements were carried out at monthly intervals, although in some cases, they were also carried out at quarterly intervals. The duration of the final phase of deformation depends on a number of factors listed in the introduction to this paper. The basic factors include the following: depth of exploitation $-\mathrm{H}$, mechanical properties of the rock mass, reflected in the value of the $\operatorname{tg} \beta$ parameter. The more durable the rock mass, the lower the value of this parameter. The value increases with the degree of rock mass cracking. As it results from the research (Kratzsch 1983), the method of roof control (caving, stowing) has a significant influence on the course of deformation in time. Speed of advance of the edge of extraction in the analyzed conditions was not very differentiated, which results from the fact that, in most cases, the exploitation was conducted in an urbanized area. In such cases, the high speed of exploitation causes high values of the subsidence speed, which has a detrimental effect on building structures. Therefore, the statistical analyses were performed as follows. The duration of the final phase of the deformation process was investigated depending on the depth of exploitation and the value of the $\operatorname{tg} \beta$ parameter. Separate analyses were carried out for exploitation with caving and hydraulic stowing.

On the basis of the final values of subsidence found by measurements at many points (when there were practically no increments of subsidence values in subsequent cycles), the values of parameters of S. Knothe's theory were determined using the DEFK-Win program (Ścigała 2013):

a - coefficient of roof control and $\beta$ tangent parameter. Thus, the value of the parameter $r$ was also known. With a complete set of geodetic measurement results showing the course of benchmarks' subsidence over time and with maps presenting the exploitation that was carried out, it was possible to determine in certain cases the duration of the final phase of the surface deformation process in the manner given above for point $\mathrm{P} 1$. In the case of the location of measurement points, as in the case of point $\mathrm{P} 2$, the knowledge of the radius of the influence range $-r$ was not necessary at this stage of the analyzes. Subsequent analyses were carried out in the manner described in the further part of the work using linear regression with the Statistica program.

\section{Research area}

The area of research was the Upper Silesian Coal Basin located in the southwestern part of Poland and partly in the Ostrava-Karvinsk region (Czech Republic) (Fig. 3). The geological structure of the Basin is varied (Jureczka et al. 2019). Generally, the rock mass consists of overburden and productive carboniferous structure. Overburden consists of quaternary layers, built of sands, clays, and gravels of variable thickness. The overburden also includes tertiary formations formed mainly of clays and sandstones, as well as Triassic formations built of limestone. Under the 


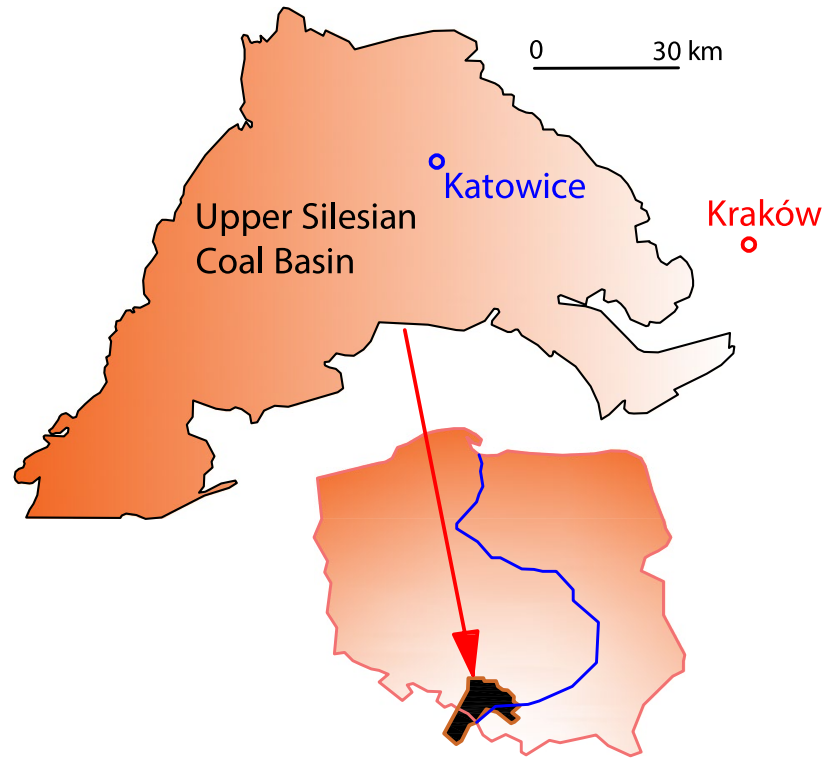

Fig. 3 Location of the Upper Silesian Coal Basin in Poland

overburden layers, there is a carboniferous structure built of claystone, mudstone, sandstone, and coal seams. In the $70 \mathrm{~s}$ of the previous century, there were 72 working mines in this area. Currently, after the liquidation of a number of unprofitable mines and those whose resources have been depleted, 20 hard coal mines operate. They extract coal from seams with a thickness of $1.5 \mathrm{~m}$ to approx. $4.0 \mathrm{~m}$ at a depth of approx. $400 \mathrm{~m}$ to approx. $1000 \mathrm{~m}$. A major part of extraction is obtained as a result of exploitation of the longwall system with roof caving. Exploitation with hydraulic stowing is carried out sporadically, only under important building structures, in several mines. Speed of advance of the edge of extraction is around 5-10 m per day.

\section{Exploitation with roof caving}

In the case of exploitation with roof caving, the following zones occur above the exploited seam: caving zone, cracking zone, and subsidence zone (Fig. 4). Longwall system with caving is widely used in all mines of the Upper Silesian Coal Basin. Therefore, majority of results of geodetic measurements recorded subsidence caused by this exploitation.

For further detailed analyses, material was used in the form results of geodetic survey carried out on 24 observation lines located above the exploitation, which was carried out at depths from approx. $300 \mathrm{~m}$ to approx. $1000 \mathrm{~m}$. They also included the data presented in the work (Strzałkowski and Ścigała 2010) and further 8 cases. Observation lines were established in 20 mines. Mines are obliged by the mining authorities to periodically determine the value of $\operatorname{tg} \beta$ parameter. In many cases, the identification of this parameter value was carried out at the request of the mines, also by the author. The method of determining the value of the $\operatorname{tg} \beta$ parameter was presented in the papers (Ścigała 2013; Białek et al. 2020). Table 1 compares the following values: depth of exploitation, $\operatorname{tg} \beta$ parameter, and duration of the final phase of subsidence process. The method of determining the duration of the final stage (when the increments of subsidence values between two consecutive measurements were less than $10 \mathrm{~mm}$ ) of the subsidence process is described in the previous section.

where:

$\mathrm{H}$ - depth of exploitation, $\mathrm{m}$

Tangent $\beta$ - parameter of Budryk-Knothe theory

$\mathrm{T}_{\mathrm{k}}$ - duration of the final phase of subsidence process, months
Fig. 4 Zones of the rock mass occurring while carrying out exploitation with roof caving (Strzałkowski 2015): $\mathrm{W}_{\max }$. maximal value of subsidence, $\mathrm{h}_{\mathrm{u}}$ height of subsidence zone, $\mathrm{h}_{\mathrm{s}}$ height of cracking zone, $\mathrm{h}_{\mathrm{z}}$ height of caving zone, $g_{z}$ thickness of coal seam, $\beta$ angle of the range of influences

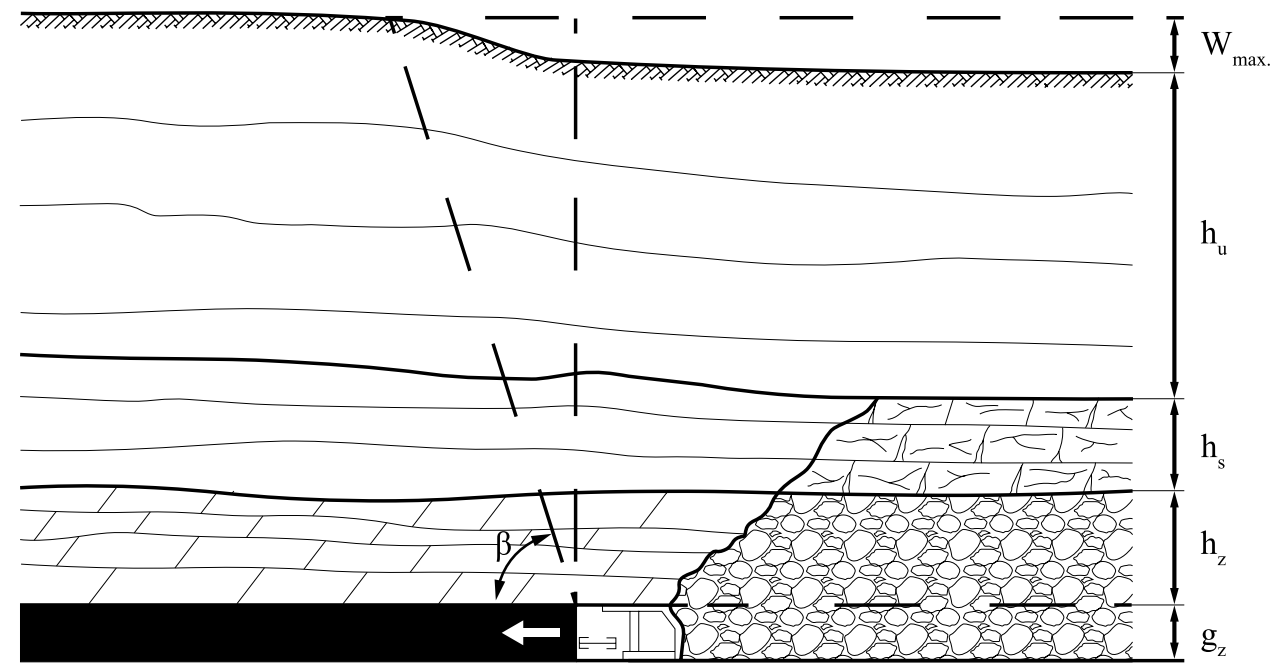


Table 1 Comparison of data used for further analyses

\begin{tabular}{|c|c|c|c|}
\hline No & $\begin{array}{l}\text { Depth of extrac- } \\
\text { tion H } \\
\text { (m) }\end{array}$ & Tangent $\beta$ & $\begin{array}{l}\text { Time Tk } \\
\text { (months) }\end{array}$ \\
\hline 1 & 290 & 3.30 & 3.0 \\
\hline 2 & 370 & 2.00 & 7.2 \\
\hline 3 & 420 & 2.40 & 6.0 \\
\hline 4 & 437 & 1.80 & 7.8 \\
\hline 5 & 476 & 2.10 & 9.0 \\
\hline 6 & 500 & 2.10 & 7.0 \\
\hline 7 & 500 & 1.80 & 11.3 \\
\hline 8 & 630 & 2.40 & 13.0 \\
\hline 9 & 630 & 2.50 & 11.5 \\
\hline 10 & 650 & 1.60 & 14.0 \\
\hline 11 & 655 & 2.10 & 15.0 \\
\hline 12 & 670 & 2.00 & 11.7 \\
\hline 13 & 670 & 2.40 & 12.0 \\
\hline 14 & 695 & 2.10 & 14.5 \\
\hline 15 & 700 & 2.10 & 16.0 \\
\hline 16 & 719 & 2.00 & 16.2 \\
\hline 17 & 745 & 2.40 & 13.0 \\
\hline 18 & 780 & 1.85 & 16.5 \\
\hline 19 & 790 & 2.40 & 15.5 \\
\hline 20 & 812 & 2.00 & 16.0 \\
\hline 21 & 840 & 2.40 & 17.0 \\
\hline 22 & 860 & 2.40 & 20.0 \\
\hline 23 & 1000 & 2.10 & 21.0 \\
\hline 24 & 1030 & 2.10 & 27.0 \\
\hline
\end{tabular}

\section{Exploitation with hydraulic stowing}

Exploitation with hydraulic stowing, as it was mentioned before, is carried out very rarely in the conditions of Upper Silesian Coal Basin. Only in case of reducing surface deformations in the area of protected buildings. In the case of this method of roof control, the void after coal extraction is filled with sand delivered by hydrotransport. Therefore, caving zone is not created, only cracking zone and subsidence zone (Fig. 5). The value of surface subsidence is around $1 / 3$ of the one observed in the case of performing exploitation with caving. Taking into account the ratio of the maximum value of subsidence to the seam thickness, expressed by the coefficient a, the situation is as follows. The value of the coefficient a in the case of exploitation with roof caving is in the range from 0.7 to 0.9 . In the case of exploitation with the use of a hydraulic stowing, it is in the range from 0.15 to 0.25 .

Table 2 presents a juxtaposition of the following: the depth of exploitation $-\mathrm{H}$, the $\operatorname{tg} \beta$ parameter and the ratio $\mathrm{H} / \operatorname{tg} \beta$, and the duration of the final phase of the subsidence process $-T_{k}$.

\section{Results of analyses and discussion}

\section{The results of the analyses in the case of exploitation with caving of the roof rocks}

Following the results of the study (Strzałkowski and Ścigała 2010), it was decided to search for a linear relationship between the duration of the final phase of the subsidence process and the depth of exploitation divided by the root of the value of $\operatorname{tg} \beta$ parameter.

The results of the analyses made with use of the Statistica 13 program are presented in Fig. 6. The figure shows the data obtained on the basis of the measurement results, regression line with confidence intervals at the level of 0.95 , and Eq. (5):

$$
T_{k}=0.03859 \frac{H}{(\operatorname{tg} \beta)^{0.5}}-4.060
$$

Fig. 5 Rock mass zones occurring during exploitation with roof caving: $\mathrm{W}_{\max }$ maximal value of subsidence, $h_{u}$ height of subsidence zone, $h_{s}$ height of cracking zone, thickness of coal seam, $\beta$ angle of the range of main influences

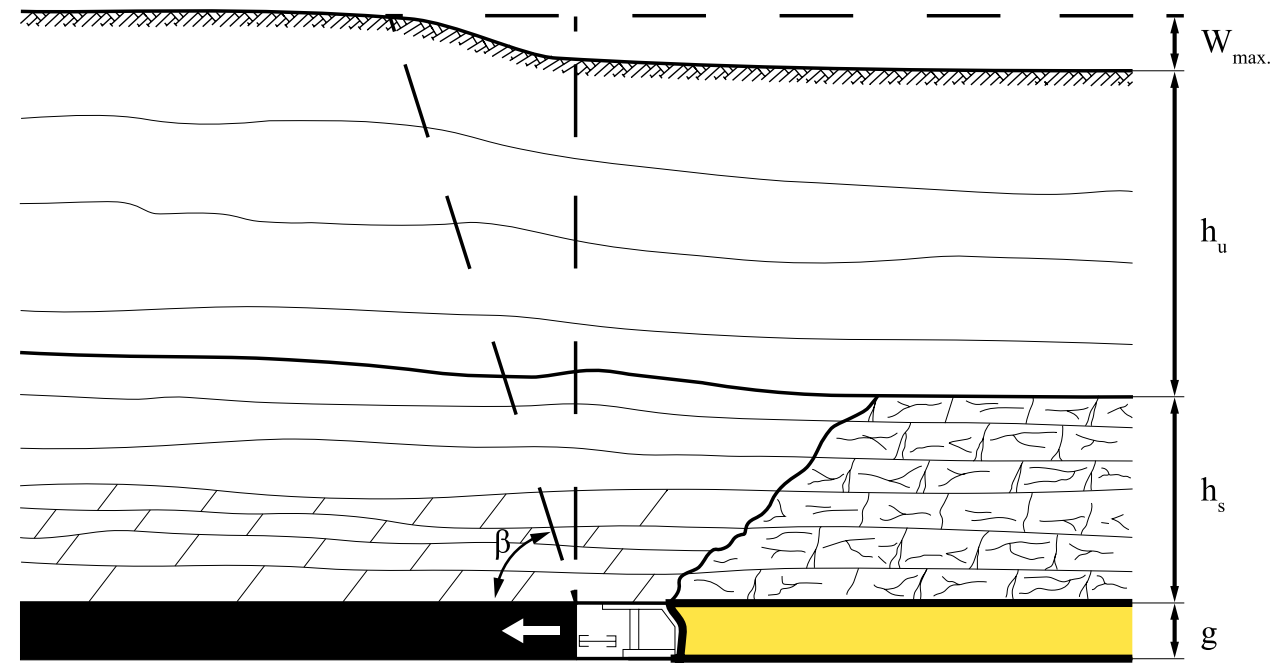


Table 2 Juxtaposition of data was used for further analyses

\begin{tabular}{llll}
\hline No & $\begin{array}{l}\text { Depth of extrac- } \\
\text { tion H } \\
(\mathrm{m})\end{array}$ & Tangent $\beta$ & $\begin{array}{l}\text { Time Tk } \\
\text { (months) }\end{array}$ \\
\hline 1 & 450 & 1.90 & 7 \\
2 & 470 & 1.90 & 8 \\
3 & 530 & 1.50 & 15 \\
4 & 535 & 1.50 & 14 \\
5 & 555 & 1.50 & 16 \\
6 & 630 & 1.65 & 13.5 \\
7 & 700 & 1.65 & 17.5 \\
\hline
\end{tabular}

The formula applies if $290 \mathrm{~m}<\mathrm{H}<1030 \mathrm{~m}$ and $1.6<\operatorname{tg} \beta$ $<3.3$

The value of the correlation coefficient was 0.95423 , which proves a very good correlation of the variables.

As can be seen from Fig. 6, not all values of the variables adopted for the analysis fell within the confidence interval at the assumed level of 0.95 . However, it should be considered that they were located close to this range.

It should be noted that, in majority of cases, the values of the $\operatorname{tg} \beta$ parameter varied within a small range from 2.00 to 2.4 .

It is illustrated in Fig. 7 - histogram of $\operatorname{tg} \beta$ parameter. As can be seen from the histogram, the variability of the parameter value is not consistent with the Gaussian distribution.

The knowledge of the value of the $\operatorname{tg} \beta$ parameter from the Upper Silesian Coal Basin mines significantly indicates that it oscillates around 2.
The above suggests that, in the conditions of Upper Silesia, the most statistically significant is the relation between the duration of the final phase of rock mass movements and the depth of mining exploitation. The Statistica 13 program was also used to check the correlation between the duration of the final phase of the deformation process and the depth of exploitation. The results of calculations are presented in Fig. 8. As can be seen from the figure, a very similar picture of the approximation compliance with that shown in Fig. 6 was obtained. The value of the correlation coefficient was 0.95314 .

$T=0.02692 H-4.419$

The figure shows that the formula (1) gave the worst compliance with the output data (determined on the basis of the measurement results - Tmeas.) Using the remaining formulas, a similar consistency was obtained in all three cases; however, formula (4) has a scope of application up to a depth of $840 \mathrm{~m}$ (see the comment to formula (4) in the sect. "Introduction"). The values of standard deviations and percentage errors for individual formulas are given below (Table 3).

Summarizing the presented results of the analyses, the following can be noted: continuing the results of the works (Chudek 2002; Strzałkowski and Ścigała 2010) based on new data obtained on the basis of geodetic measurements and statistical analyses, it was possible to obtain the formula (5), the compliance of which with the output data is higher than the formulas (1) and (4). This is evidenced by
Fig. 6 The data included in the calculations and the straight line approximating them according to Eq. (5) with the confidence intervals at the level of 0.95

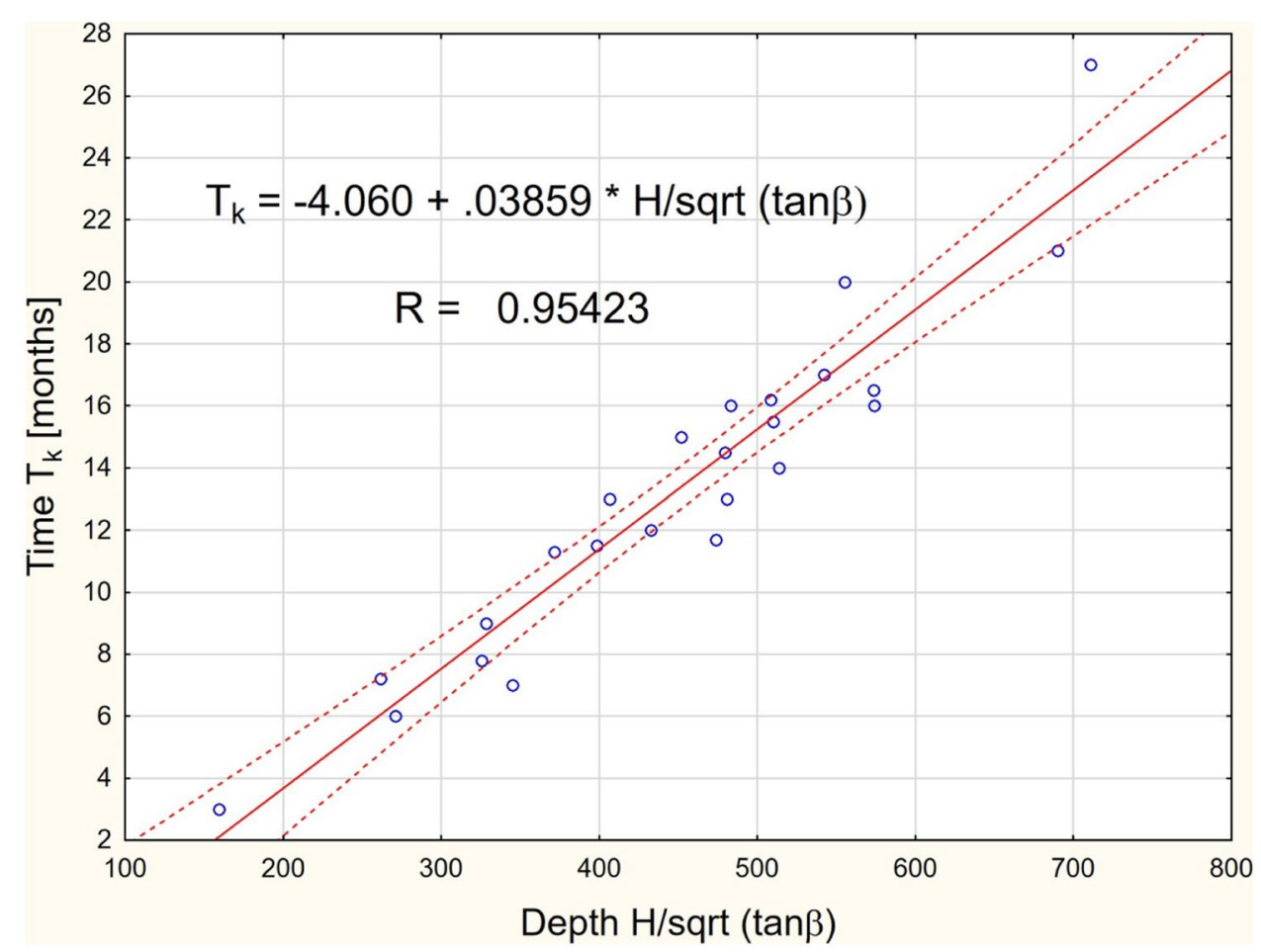


Fig. 7 Histogram of $\tan \beta$ parameter

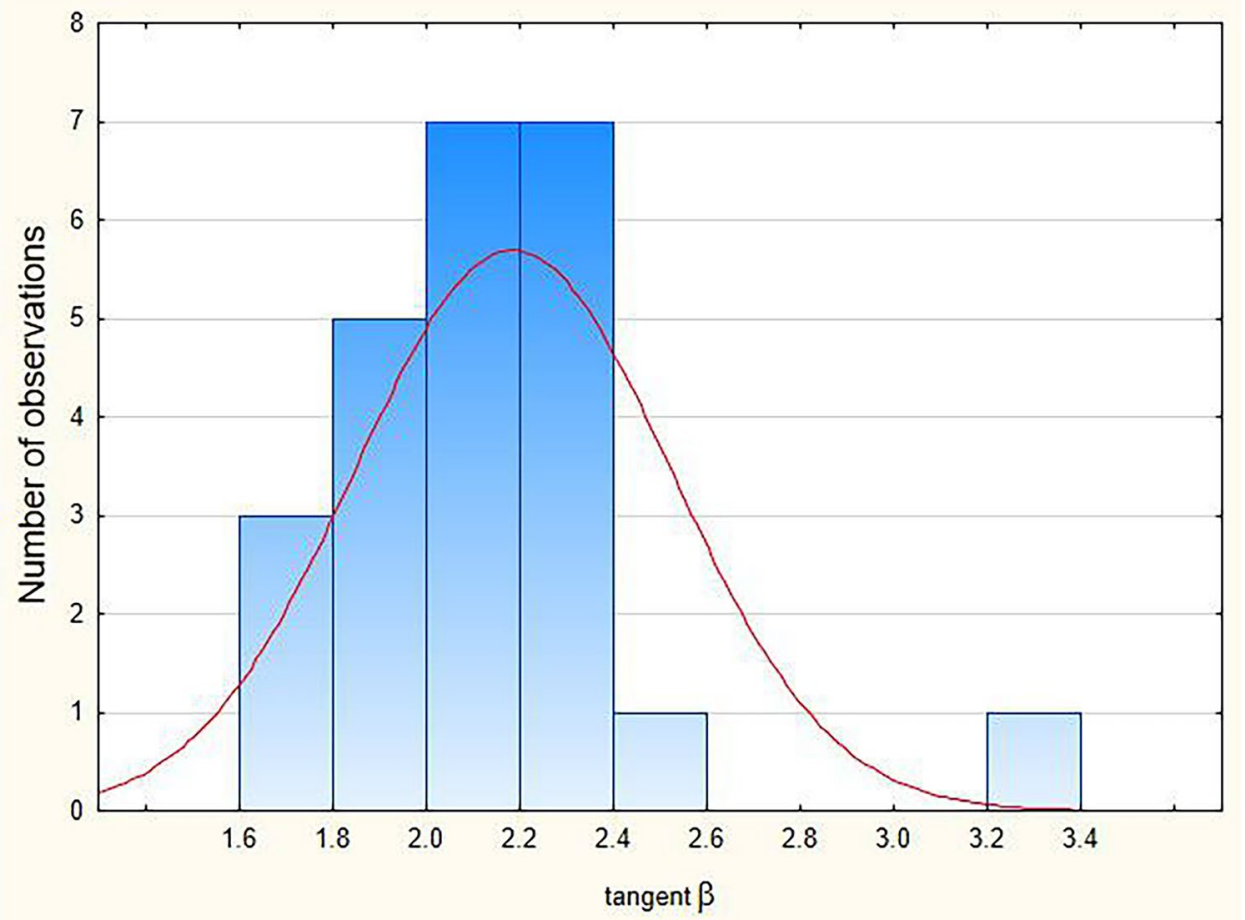

the values of standard deviations and percentage errors presented in Table 3, especially the compatibility of formula (1) with the output data is much lower than that of the other formulas. It is also visible in Fig. 9.
In the case of formula (5), which is a kind of verification of formula (4) made on the basis of new measurement data, the percentage error value was below $6 \%$, and in the case of formula (4) - over $8 \%$.
Fig. 8 Data included in the calculations and the straight line approximating them according to Eq. (6) with the confidence intervals at the level of 0.95

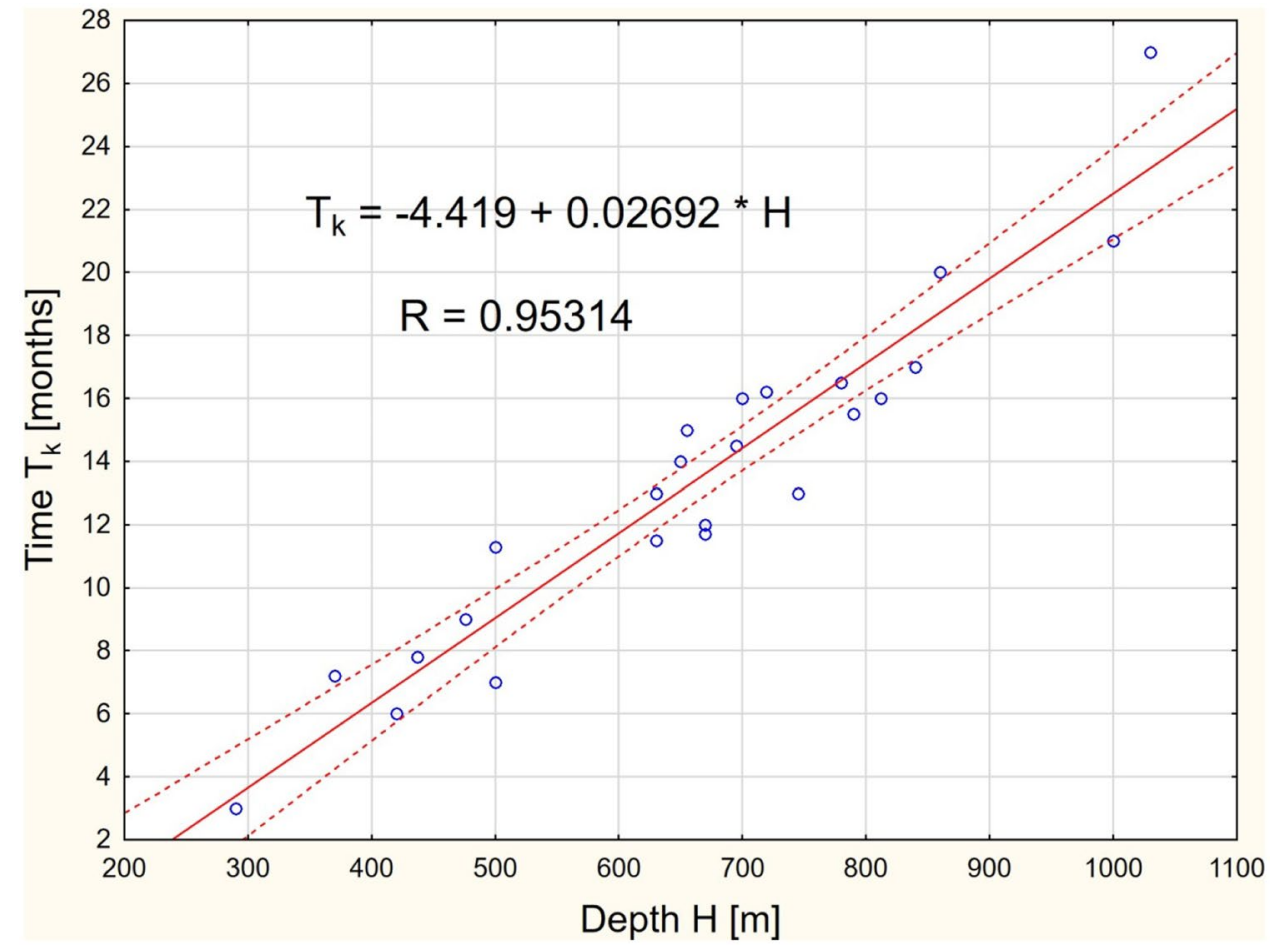


Table 3 The values of standard deviations and percentage errors obtained when using formulas (1), (4), (5) and (6)

\begin{tabular}{lll}
\hline Formula & $\begin{array}{l}\text { Standard deviation } \\
\text { (months) }\end{array}$ & $\begin{array}{l}\text { Percentage error } \\
(\%)\end{array}$ \\
\hline$(1)$ & 4.20 & 24.74 \\
$(4)$ & $2.23^{*}$ & $8.27^{*}$ \\
$(5)$ & 1.58 & 5.87 \\
$(6)$ & 1.60 & 5.93 \\
\hline
\end{tabular}

*The formula covers the scope of exploitation depth up to $840 \mathrm{~m}$

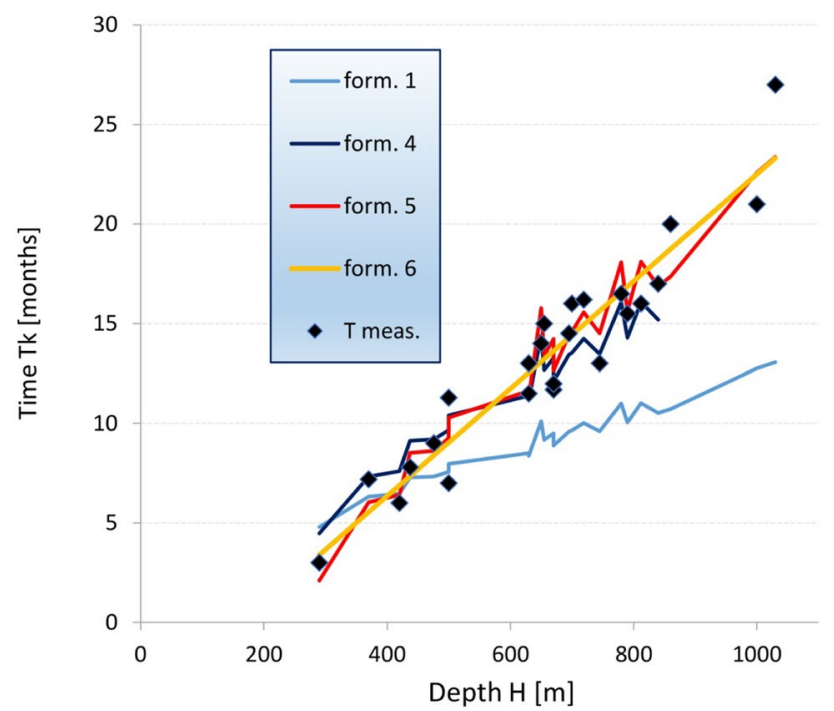

Fig. 9 Calculation results of the duration of the final phase of the deformation process according to the formulas: (1), (4), (5), (6) and based on the measurement results depending on the depth of exploitation for the data in Table 1 - Tmeas
From the information obtained in mining industry, it is known that, in the case of a large number of mines in Upper Silesia, the value of $\operatorname{tg} \beta$ parameter oscillates around the value of 2 .

This is confirmed by the data presented in Table 1 . Thus, as indicated by the results of the analyses shown in Fig. 8, the depth of exploitation has the most statistically significant influence on the duration of the final phase of the deformation process. The formulas (5) and (6) gave a comparable compliance with the initial data.

\section{The results of the analyses in the case of exploitation with hydraulic stowing}

The use of the Statistica 13 program for statistical analyses finally led to the equation in the following form:

$T K=-5.599+0.5493 \frac{H}{\operatorname{tg} \beta}$

The formula applies if $450 \mathrm{~m}<\mathrm{H}<700 \mathrm{~m}$ and $1.5<\operatorname{tg} \beta$ $<1.9$

Figure 10 presents the result of program operation, output data, regression line, and the confidence intervals at the level of 0.95 .

The comparison of the calculation results obtained according to Eqs. (2) and (7) with the output data from Table 2 is shown graphically in Fig. 11. In the case of Eq. (2), the standard deviation was 2.12 months, and the percentage error $13.28 \%$. In the case of Eq. (7), the standard deviation was 1.06 months, and the percentage error $6.07 \%$.
Fig. 10 The data included in the calculations and the straight line approximating them according to Eq. (7) with the confidence intervals at the level of 0.95

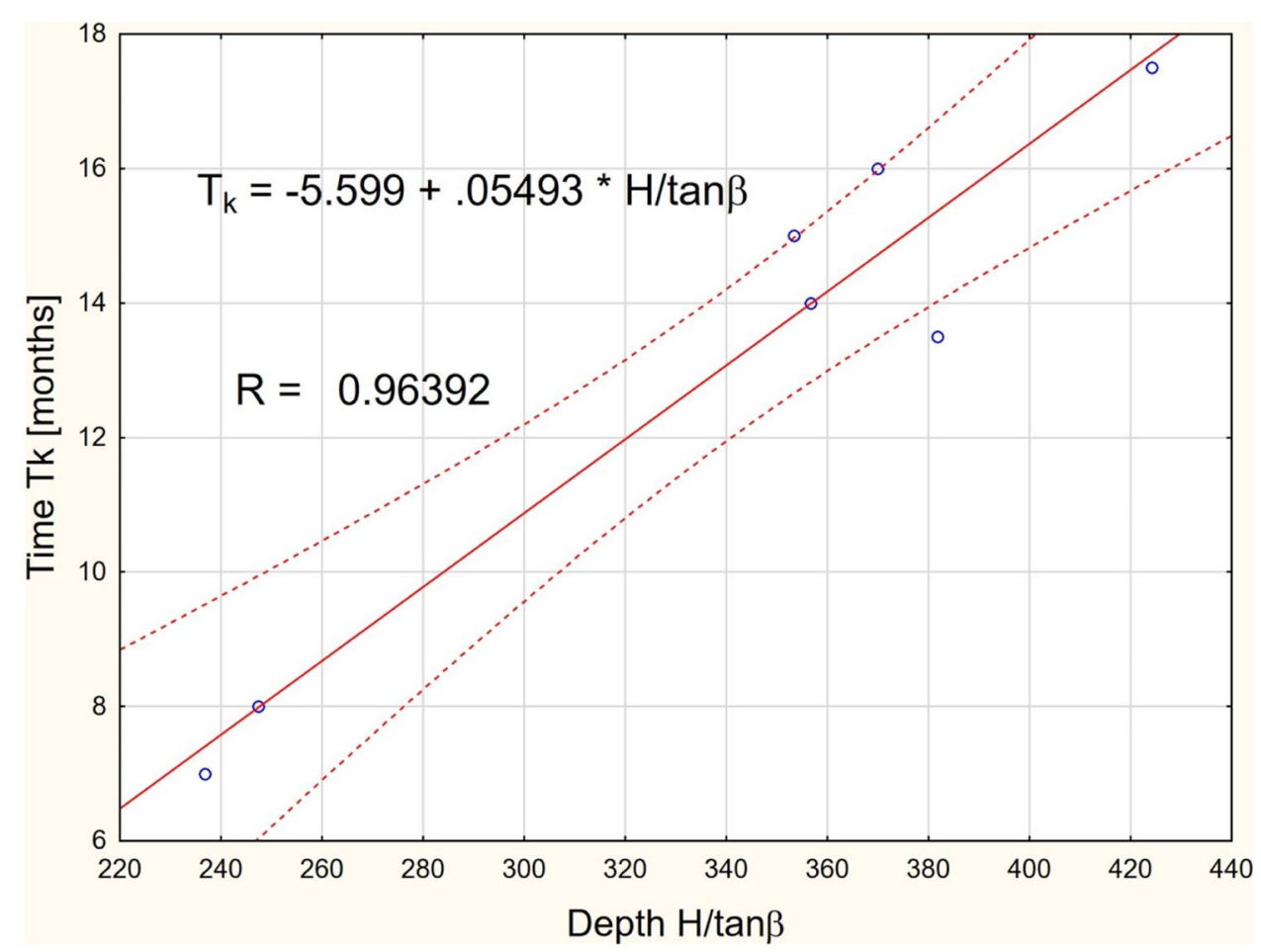


Fig. 11 Comparison of the calculation results obtained according to Eqs. (2) and (7) with the output data from

Table 2 - Tmeas

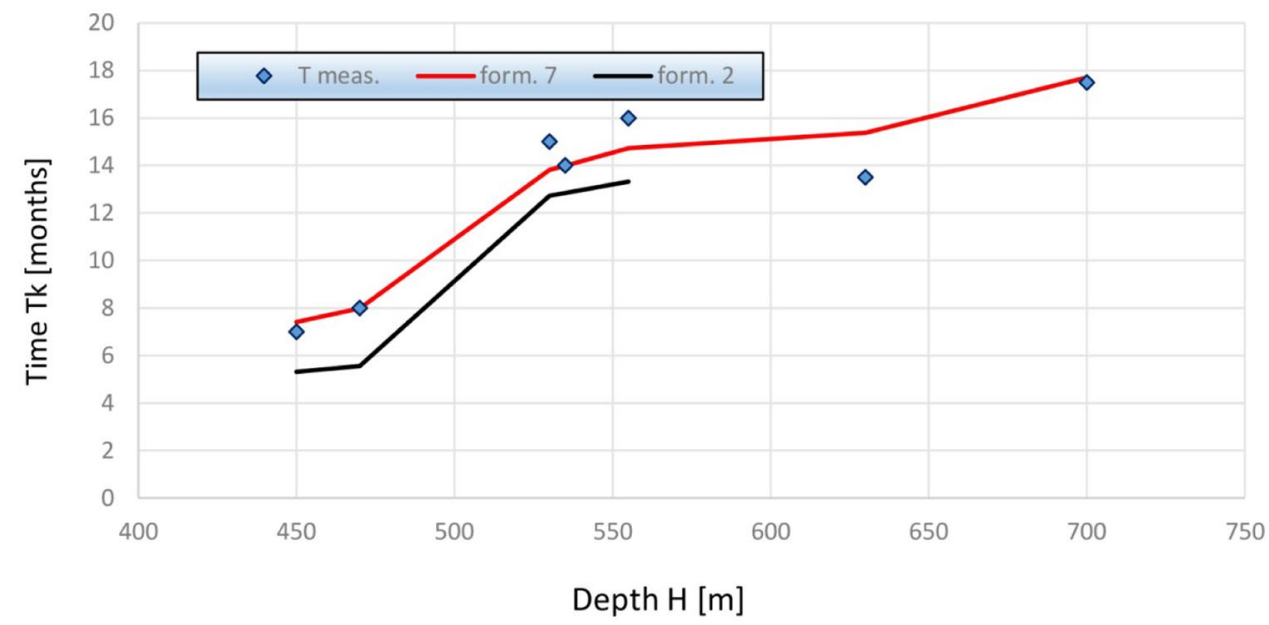

\section{Discussion}

As noted earlier, many factors influence the duration of the final phase of rock mass displacement. One of them is the structure of the rock mass and its strength properties, expressed indirectly by the value of the parameter $\operatorname{tg} \beta$. Therefore, it is worth presenting in more detail the dependence of the value of this parameter on the factors characterizing the geological and mining conditions of the exploitation. As a result of many years of research, J. Zych (1985) presented an empirical formula expressing the value of this parameter:

$\tan \beta=(H-h)^{f_{t}\left(1-f_{g}\right)}-f_{g}+0.5 \frac{h}{H}$

where

$f_{t}=\frac{1.8-f_{s}}{2.8}$

$f_{g}=\sqrt{\frac{f_{s}-1.0}{g}}$

$\mathrm{g}$ - thickness of the exploited seam, $\mathrm{m}$

$\mathrm{h}$ - thickness of loose overburden rocks, $\mathrm{m}$

$\mathrm{H}$ - depth of exploitation, $\mathrm{m}$

The $f_{s}$ coefficient characterizes the mechanical properties of the rock mass, and its value is calculated as a weighted average for all layers, according to the relationship:

$f_{s}=\frac{\sum_{i=1}^{n} f_{s i}}{\sum_{i=1}^{n} h_{i}}$

$\mathrm{h}_{\mathrm{i}}$ - thickness of layer $\mathrm{i}, \mathrm{m}$

$\mathrm{n}$ - number of layers.
The value of $\mathrm{f}_{\mathrm{si}}$ for individual layers is expressed by the relationship proposed by Zych and Strzałkowski (Drzęźla et al. 1993):

$f_{s i}=1+0.1 \sqrt{\frac{R_{c i}}{R_{r i}}+\frac{R_{r i}}{R_{c i}}}$

$\mathrm{R}_{\mathrm{ri}}$ - tensile strength of layer i, MPa.

$\mathrm{R}_{\mathrm{ci}}$ - tensile strength of layer i MPa.

Summarizing the above, it should be stated that the value of the parameter $\operatorname{tg} \beta$ depends on the following quantities:

- Rock mass strength properties, expressed by compressive and tensile strength,

- thickness of loose overburden rocks,

- depth of exploitation,

- thickness of the exploited seam.

The height of the caving zone depends on the thickness of the exploited seam.

According to the work (Chudek 2002), it may be up to 5 times of seam thicknesses. The height of the abovementioned zone may affect the duration of the surface subsidence process, which also indirectly is confirmed by the formula (8). However, attempts to depend the time value Tk on the deposit thickness did not give positive results. It could have been caused by both small variations in the thickness of the seams (from approx. $1.5 \mathrm{~m}$ to approx. $3.0 \mathrm{~m}$ ) and the influence of thickness on the value of the $\operatorname{tg} \beta$ parameter. The thickness of the seams exploited with roof caving was from approx. $1.5 \mathrm{~m}$ to approx. $2.5 \mathrm{~m}$. Thicker seams (approx. $3 \mathrm{~m}$ ) were exploited with hydraulic stowing. Thus, the height of the caving zone in relation to the depth of exploitation could not be large, which probably resulted in a lack of correlation between the seam thickness (height of the caving zone) and the time value Tk. 
It should also be noted that, in the case of exploitation with roof caving in the conditions of the Upper Silesian Coal Basin, not only the differentiation in the thickness of the exploited seams is small but the structure of the rock mass and its properties are also similar in many cases, which is manifested by a small variation in the value of the parameter $\operatorname{tg} \beta$ - with a predominance of cases where this value oscillates around 2. Hence, the connection between the duration of the final phase of subsidence and the depth of exploitation can be considered a usable effect of the work and an element of novelty in relation to the previously presented results. Using the formula (6) makes the analysis much easier, and the results of the calculations do not differ significantly from the results obtained from the formula (5). Taking into account the various factors, indicated in the introduction, which influence the duration of the final stage of subsidence of the mining area and the comments presented above, it can be concluded that the proposed formulas take into account the factors with the most significant impact. They also allow for obtaining greater compliance with the measurement results than the previously developed formulas.

\section{Summary and conclusions}

As a part of this study, which is a continuation of the research presented in the works (Chudek et al. 2000; Strzałkowski and Ścigała 2010), the impact of the depth of exploitation and the $\operatorname{tg} \beta$ parameter (which is dependent on the strength properties of the rock mass) on the duration of the final phase of the deformation process was analyzed. This phase is understood as the time period measured from the end of exploitation (or moving away from the considered point to a sufficiently large distance) to the end of the deformation process. Of course, the accuracy of determining this time interval is significantly influenced by the frequency of measurements. The analyses were performed separately for cases of exploitation with caving of roof rocks and exploitation with hydraulic stowing. The analyses and their results allow the formulation of the following conclusions and statements:

1. Knowing the duration of the final phase of deformation process is important due to investments in the area of active and liquidated mines. It is also relevant in the case of assessment of the impact time of mining exploitation (and therefore its scope) on objects on the surface. It also matters in the case of pursuing claims for the so-called mining damage.

2 . The method of analyzing the results of geodetic measurements can be used in the case of determining the duration of the final phase of the deformation process in other hard coal basins and other mineral resources exploited with underground methods.
3. A significant relationship was found between the duration of the final phase of deformation process and the depth of exploitation as well as the value of the $\operatorname{tg} \beta$ parameter in the case of mining with roof rocks caving. The formula (5) obtained as a result of the analyses proves the correctness of the above statement. Due to the most common value of $\operatorname{tg} \beta$ parameter, amounting to approx. 2 in the analyzed conditions, in the light of the research results presented in the paper, it is possible to apply the relation expressing the duration of the final phase of the deformation process depending on the depth of exploitation - formula (6). A similar compliance with the observation results was obtained as in the case of formula (5).

4. In the case of exploitation with hydraulic stowing, the formula (7) was obtained, which also proves the dependence of the duration of the final phase of the deformation process on the depth and mechanical properties of the rock mass.

Acknowledgements The author thankfully acknowledges the Silesian University of Technology, Poland, for providing all the facilities to perform the research work.

Funding This work was supported by the Department of Geomechanics and Underground Construction, Faculty of Mining, Safety Engineering and Industrial Automation, Silesian University of Technology, Gliwice, Poland.

\section{Declarations}

Conflict of interest The author declares no competing interests.

Open Access This article is licensed under a Creative Commons Attribution 4.0 International License, which permits use, sharing, adaptation, distribution and reproduction in any medium or format, as long as you give appropriate credit to the original author(s) and the source, provide a link to the Creative Commons licence, and indicate if changes were made. The images or other third party material in this article are included in the article's Creative Commons licence, unless indicated otherwise in a credit line to the material. If material is not included in the article's Creative Commons licence and your intended use is not permitted by statutory regulation or exceeds the permitted use, you will need to obtain permission directly from the copyright holder. To view a copy of this licence, visit http://creativecommons.org/licenses/by/4.0/.

\section{References}

Białek J, Wesołowski M, Mielimąka R, Sikora P (2020) Deformations of mining terrain caused by the partial exploitation in the aspect of measurements and numerical modeling. Sustainability 12. https:// doi.org/10.3390/su12125072

Bell FG, Stacey TR, Genske DD (2000) Mining subsidence and its effect on the environment: some differing examples. Environ Geol 40:135-152. https://doi.org/10.1007/s002540000140 
Bell FG, Donnelly LJ (2006) Mining and its impact on the environment. CRC Press, London

Blachowski J, Cacoń S, Milczarek W (2009) Analysis of post-mining ground deformations caused by underground coal extraction in complicated geological conditions Acta Geodyn Geomater 6:351-357

Cui X, Zhao Y, Wang G, ZhangB, Li C (2020) Calculation of residual surface subsidence above abandoned longwall coal mining. Sustainability 12:1-12. https://doi.org/10.3390/su12041528

Chudek M (2002) Geomechanics with the basics of mining environment and land surface protection. Publishing House of Silesian University of Technology, Gliwice (in Polish)

Chudek M, Strzałkowski P, Ścigała R (2000) Duration of post-mining ground surface deformation depending on geological and mining conditions. Budownictwo Górnicze i Tunelowe 3:38-42 (in Polish)

Didier C (2009) Postmining management in France: situation and perspectives. Risk Anal Wiley 29(10):1347-1354. https://doi.org/10. 1111/j.1539-6924.2009.01258.xineris-0096194

Drzęźla B, Zych J, Strzałkowski P (1993) Forecasting deformation of the land surface under the influence of mining extraction. Publishing House of Silesian University of Technology, Gliwice (in Polish)

Flaschentrager H (1957) Cosiderations on ground movement phenomena based on observations made in the left bank Lower Rhine region. Proc Eur Cong Ground Movt: 58-73

Genis M, Akcin A, Aydan O, Bacak G (2018) Investigation of possible causes of sinkhole incident at the Zonguldak Coal Basin, Turkey. Geomech Eng 16(2):177-185. https://doi.org/10.12989/ gae.2018.16.2.177

Ju M, Longiun D, Guoyan Z, Xibing L (2019a) Qualitative method and case study for ground vibration of tunnels induced by fault-slip in underground mine. Rock Mech Rock Eng 52:1887-1901

Ju M, Longjun D, Guoyan Z, Xibing L (2019b) Ground motions induced by mining seismic events with different focal mechanisms. 116:99-110

Jureczka J, Ignatowicz A, Zdanowski A (2019) Polish hard coal basins - and overview of the history of the researche of the National Geological Institute. Przegląd Geologiczny 67:578-583 (in Polish)

Kapp WA (1973) Mine subsidence. Proc Symp Subsidence in Mines, Australian Inst. Min. Met.:1/1-1/9

Karfakis MG (1993) Residual subsidence over abandoned coal mines. In. Brown JA, Fairhurst ET, Hoek E. (ed) Comprehensive Rock Engineering 5, Hudson, Pergamon Press, Oxford, UK: 451-476

Knothe S (1953) The equation of finally formed profile of subsidence trough. Archive of Mining and Metallurgy, 1/ 1: 22-38 (in Polish)

Kratzsch H (1983) Mining Subsidence Engineering; Springer-Verlag: Berlin, Heidelberg, New York

Li J, Liu C (2017) Formation mechanism and reduction technology of mining-induced fissures in shallow thick coal seam mining. Shock Vib 6. https://doi.org/10.1155/2017/1980817

Orchard RJ (1956-57) Surface effects of mining - the main factors. Trans I Min E 116 Part I: 942 - 944

Orchard RJ, Allen WS (1974) Time - dependence in mining subsidence. Minerals and the Environment, I. M. M., London: 634 - 659
Orwat J (2020) Causes analysis of occurrence of the terrain surface discontinuous deformations of a linear type. J Phys 1426:1-9. https://doi.org/10.1088/1742-6596/1426/1/012016

Peng S (2008) Coal mine ground control. Morgantown: West Virginia University, United States, 3rd ed

Psamehmetoglu AG (1972) An investigation into time - dependent aspects of mining subsidence. Dissertation, University of Nottingham, UK

Strzałkowski P, Ścigała, R (2010) Determination of the duration of surface subsidence caused by underground extraction. Schriftenfreihe des Institutes fur Markscheidewewsen und Geodäsie an der Technischen Universitat Bergakademie Freiberg: 77-81

Strzałkowski P (2015) General Mining. Publishing House of Silesian University of Technology, Gliwice (in Polish)

Strzałkowski P (2019) Sinkhole formation hazard assessment. Environ Earth Sci 78. https://doi.org/10.1007/s12665-018-8002-5

Strzałkowski P, Ścigała R (2020) Assessment of post - mining terrain suitability for economic us. Int J Environ Sci Technol 17:31433152. https://doi.org/10.1007/s13762-019-02617-8

Strzałkowski P (2021) The influence of selected mining and natural factors on the sinkhole creation hazard based on the case study. Environ Earth Sci 80, 117. https://doi.org/10.1007/ s12665-021-09403-1

Ścigała R, Szafulera K (2019) Linear discontinuous deformations created on the surface as an effect of underground mining and local geological conditions-case study. Bull Eng Geol Environ 1-10. https://doi.org/10.1007/s10064-019-01681-1

Ścigała R (2013) The identification of parameters of theories used for prognoses of post mining deformations by means of present software. Arch Min Sci 58:1347-1357. https://doi.org/10.2478/ amsc-2013-0093

Szpetkowski S (1978) The measurement on mining areas. Publishing House „Śląsk”. Katowice (in Polish)

Vervoort A, Declercq P (2017) Surface movement above old coal longwalls after mine closure. Int J Min Sci Technol 27:481-490. https://doi.org/10.1016/j.ijmst.2017.03.007

Wang ZS, Deng KZ (2012) Residual subsidence prediction of abandoned mine goaf based on wavelet support vector machines. Adv Mater Res 330-336. https://doi.org/10.4028/www.scientific.net/ amr.524-527.330

Whittaker BN, Reddish DJ (1989) Subsidence occurrence, prediction and control. Developments in geotechnical engineering. Elsevier, Amsterdam

Yao XL, Reddish DJ (1994) Analysis of residual subsidence movements in the UK coalfields. Q J Eng GeolHydrogeol 27:15-23. https://doi.org/10.1144/GSL.QJEGH.1994.027.P1.04

Wu C, Linming D, Guangyao S, Yawei H (2020) Fault-induced coal burst mechanism under mining-induced static and dynamic stresses. In Press, Engineering

Zych J (1985) Variability of parameters of the theory of S. Knothe and T. Kochmanski in the light of geodetic research. Publishing House of Silesian University of Technology, Gliwice, (in Polish) 